\title{
Effectiveness of Neuro Scientific Research-based Pedagogy in Science
}

\author{
Asrat Dagnew \\ College of Education and Behavioral Science, Bahir Dar University, Ethiopia
}

Copyright $(2017$ by authors, all rights reserved. Authors agree that this article remains permanently open access under the terms of the Creative Commons Attribution License 4.0 International License

\begin{abstract}
The Purpose of this study was to investigate the effectiveness of neuroscience research - based pedagogy in science education. The specific objectives of the study answer the basic research questions: What are the current implications of neuroscience research and to what extent will neuroscience research into biological mechanisms learning, memory, attention, and other brain functions inform educational practices and science teaching in the future? In this investigation, experimental research design was employed. Along with this, a sample of thirty six students was drawn from a total of seventy-two student population using purposive random sampling technique. Then, based on the pre-test scores, mixed ability groups such as eighteen high and eighteen low scoring that are (36) students in each group as experimental(15 $\mathrm{F}$ and $21 \mathrm{M})$ and control(14 $\mathrm{F}$ and $22 \mathrm{M})$ groups were assigned respectively. Based on the hypothesis formulated, questionnaire was used as the instruments of data collection. The research data was collected from both experimental and control groups. Populations of the study were selected by purposive simple random sampling technique. Two way ANOVA as statistical techniques had been used to investigate the efficacy of neuroscience research based pedagogy in science achievement among secondary school students.
\end{abstract}

Keywords Education, Neuroscience Research, Pedagogy, Secondary Schools

\section{Introduction}

There is a paradigm shift in teaching learning process mainly due to the new theories and approaches constructivism, multiple-intelligence, active learning and inquiry-based learning - which have eliminated the impediments and limitation of the traditional way of teaching and improving the quality of instruction. In the recent past, various theoretical propositions and empirical studies were carried out to come up with different views for more effective teaching. One of these views brain-based learning includes accepting the rules of brain processing and organizing the teaching according to these rules in the mind, for meaningful learning. In the contemporary world, where we are deluged with journal papers, it is all but impossible to keep up with crucial developments in closely related areas of science something that I find increasingly essential to this research as science becomes ever more interdisciplinary Bruner, [1]. Mind, brain and education science is the most innovative thinking being applied to enhancing teacher quality and student achievement today. However, few teachers and school learners understand how the brain learns, works and changes.

Science education has made significant advances over the last three decades. However, learning outcomes have been modest - especially for minority populations - and international comparisons show the US losing ground. Additionally, reports show that there is a decline in interest in pursuing careers and advanced degrees in science. While there are many systemic and institutional challenges that contribute to our slow progress, one must consider that the most likely reason for our persistent difficulties in teaching science and fostering an interest in science careers is the nature of the learning experiences we provide our students and the limits of our current instructional practices. Neuroscience can play a central role in providing an explicit and empirically grounded rationale for a change of direction, by advancing our understanding of the neural underpinnings of effective pedagogical learning.

Interestingly, researchers have actually done research on whether people are susceptible to claims based on neuroscience. In 2016, two separate studies showed how neuroscience information could influence people's perceptions and decision making. McCabe and Castel [2] found that adding neuroscience images to articles prompted readers to rate the scientific reasoning in those articles more highly than if a bar chart was added or if there was no image added. Weisberg, Keil, Goodstein, Rawson, and Gray [3] found that adding extraneous neuroscience information to poorly-constructed explanations prompted novices and college students (in a neuroscience class) to rate the explanations as more satisfying than if there was no 
neuroscience information. New and ongoing findings from the neuro and cognitive sciences have produced a fast frontier of knowledge on how brain processes, stores, and retrieves information. As educators at all levels have increasingly recognized their role as consumers of this emerging knowledge, translating brain research into instructional practice often becomes a challenge for educational practitioners.

Brain-based learning is concerned with creating powerful learning environments based up on emotional connections Bryan [4]. Meaning learning occurs when faculty transition from a teacher-centered environment to one that is learner -centered Thompson [5]. Caine and Caine [6] defined brain based learning as recognition of the brain code for meaningful learning and adjusting the teaching process in relation to those codes. Studies in the field of neurobiology have improved understanding of how brain functions and how learning is formed. In recent years, a new field of enquiry has burst onto the scene with the hope of finally unlocking the secret of how learning takes place. It has been referred to as educational neuroscience, neuro education and mind, brain and education.

Brain to secondary school students sought to 1) Create an expert cadre of teachers who would integrate neuroscience concepts, activities, demonstrations, and experiments into their classrooms; and 2) Increase teachers' use of inquiry-based teaching. The underlying premise of the program was that teachers would utilize in their own classrooms the same pedagogical approaches employed when they learned neuroscience. Thus, this study was conducted to understand the effectiveness of a long-term, sustained professional development program on science teaching practice.

Laughbaum [7] proposed a study about the implication of neuroscientific research on teaching algebra. This study makes an argument that algebra should be taught through functional approach, implemented with a graphing calculator so that one can seamlessly capitalize on the brains normal functioning. In teaching algebra one should strongly consider functional approach with tools like: Cognition, neural process of association, pattern recognition, attention, visualization and enriched classroom environment.

The proposed study is not merely the implication of neuroscience research; rather devising modalities to implement pedagogy for science subjects. The emerging pedagogy will be primarily based on cognitive and neural process of association, pattern recognition, attention, visualization, priming, enriched teaching environment and memory. The present proposed study was designed to influence our existing knowledge in terms of devising innovative pedagogy for science and providing help in solving various science problems and thus make teachinglearning process more meaningful and application oriented. Attempt was being made to bridge the existing gap in cognitive neuroscience research, brain-based learning and their implications in the field of education.
Educational neuroscience is an emerging effort to integrate neuroscience methods, particularly functional neuron imaging, with behavioral methods to address issues of learning and instruction Campbell [8]. Investigating image -based perception and reasoning in geometry and reported that brain and body activities that correlate in valid and reliable manner, and with high degree of statistical significance, with different aspects of geometrical image-based perception and reasoning into various modalities of geometrical cognition to enhance our understanding of mathematics-learning, instruction and assessment. Based on the above reasons, therefore, the researcher became interested to investigate the effectiveness of neuroscientific research-based pedagogy in science. Hence, hypothesis of the study is designed as follows:

"Students taught through neuroscientific research-based pedagogy achieve better in science than those taught through conventional method".

The general objective of the study was to investigate the effectiveness of neuroscientific research-based pedagogy in science. Specifically, the study was carried out to develop neuroscience research-based pedagogy in teaching science at secondary school level, to examine the effectiveness of neuroscience research-based pedagogy in teaching science at secondary school level and to assess the achievements of boys and girls in science taught through neuroscience research-based pedagogy.

\section{Materials and Methods}

This study was focused on the existing problems of academic performance of first cycle secondary school students. The study was mainly a quantitative study and it adopted an experimental research design. The equivalent/parallel group (post-test only) design was most suitable for the present study.

\subsection{Population, Sample and Sampling Techniques of the Study}

Currently Ethiopian education system has primary and secondary level. Each level has two cycles. Hence, at secondary school level there are first cycle secondary school (grade 9 and grade 10) and second cycle secondary school (grade 11 and grade 12). Among these, the target of this study was Fasilo first cycle secondary school (grade 9). The total numbers of students in the selected school were 72 . The investigator used purposive random sample technique to select sample for the study Garrett [9]. The selected sample was divided into two equivalent groups i.e. one experimental group and one control group based on their $9^{\text {th }}$ grade levels. Each group comprises 36 students. The experimental design (simple random design) was illustrated in the table below: 
Table 1. Simple random Design

\begin{tabular}{|c|c|c|c|}
\hline Group & N & Treatment & Post-test (only) \\
\hline Experimental & 36 & NSRBP & Achievement test \\
\hline Control & 36 & $\ldots \ldots \ldots \ldots \ldots$ & Achievement test \\
\hline
\end{tabular}

\subsection{Source of Data}

First cycle secondary school students (grade 9) were used as a source of data for the study.

\subsection{Data Gathering Instruments}

The present study was aimed at determining the effectiveness of neuroscience research-based pedagogy in science as independent variables and achievement of students as dependent variables. For this purpose, the investigator had to administer the science achievement test. The achievement test was developed by the researcher himself. To collect the required data, the researcher used the self-developed science achievement test which consists of 85 items. 75 were objective type items and 10 were short answer type items of 100 marks. The areas covered in this test were $p$ Chemistry, Physics and biology. Teachers' neuroscience content knowledge was measured with a short pre- and post-test on neuroscience. A post-test was different from the pre-test in content but the same in form constructed in the unit taught by the researcher and validated by the language expert was administered to both groups after treatment. It had 75 close-ended questions with four alternatives. Then the test was collected, corrected and recorded by the researcher. Questions probed understanding of central nervous system processes underlying neuronal function or observable classroom behaviors; for example, "One of your students has been studying hard for a test about the brain. What changes would have occurred in the students' brain as a result of their efforts?"

The validity of test was checked by the investigator using the face validity with the help of subject experts and eminent educationists with long experience in the field of science. According to them, test has content validity of the test was examined in terms of the coverage of the content and instructional objectives. It is evident from the table (blue print of the science achievement test). It covers all the topics adequately as per the guideline given by the Ministry of education, Addis Ababa MOE [10]. A three dimensional blue print showing coverage of content, instructional objectives and type of items was prepared by referring the standard text book of grade 9 in consultations with the guiding teacher.

Table 2. Blue print of the achievement test in science

\begin{tabular}{|c|c|c|c|c|c|c|c|}
\hline $\begin{array}{l}\text { Chemistry } \\
\text { (topics) }\end{array}$ & Objective & $\begin{array}{c}\text { Short } \\
\text { Answer }\end{array}$ & Knowledge & Understanding & Application & Total & $\%$ \\
\hline States of matter & 7 & 1 & $\begin{array}{c}\text { Chemistry } \\
\text { Topics }\end{array}$ & 5 & 4 & 9 & 10.50 \\
\hline $\begin{array}{c}\text { How states of } \\
\text { matter changes }\end{array}$ & 8 & 1 & 4 & 2 & 4 & 10 & 11.36 \\
\hline Mixture & 5 & 1 & 2 & 4 & 1 & 7 & 8.20 \\
\hline $\begin{array}{c}\text { Colloidal Solution } \\
\text { \& suspension }\end{array}$ & 5 & - & - & 1 & 1 & 2 & 2.27 \\
\hline Total & 25 & 3 & 6 & 12 & 10 & 28 & 32.33 \\
\hline \multicolumn{8}{|c|}{ Physics Topics } \\
\hline Motion & 5 & - & 1 & 4 & 1 & 5 & 5.88 \\
\hline $\begin{array}{c}1^{\text {st }} \& 2^{\text {nd }} \text { law of } \\
\text { motion }\end{array}$ & 5 & 1 & 3 & 1 & 2 & 6 & 7.05 \\
\hline Force & 5 & 1 & 1 & 2 & 3 & 6 & 7.05 \\
\hline Types of force & 5 & 1 & 3 & 1 & 1 & 6 & 7.05 \\
\hline Sound & 5 & 1 & 4 & 1 & - & 4 & 4.70 \\
\hline Total & 25 & 4 & 12 & 9 & 7 & 27 & 32.83 \\
\hline \multicolumn{8}{|c|}{ Biology Topics } \\
\hline $\begin{array}{c}\text { Diversity in living } \\
\text { organisms }\end{array}$ & 5 & 1 & 1 & 2 & 1 & 4 & 4.70 \\
\hline Tissue & 6 & 1 & 2 & 6 & - & 8 & 9.41 \\
\hline Plant Tissue & 8 & - & 5 & 3 & 1 & 8 & 9.41 \\
\hline Animal Tissue & 1 & 1 & 1 & 1 & - & 2 & 2.35 \\
\hline Nitrogen Cycle & 5 & 1 & 3 & 3 & - & 6 & 7.05 \\
\hline Total & 25 & 4 & 12 & 15 & 2 & 28 & 32.92 \\
\hline Grand Total & 75 & 10 & 30 & 36 & & & \\
\hline
\end{tabular}

(Total of knowledge, understanding and application: 85 items) 
The test was administered on the learner of control group and the experimental group when the statement was over.

\subsection{Statistical Techniques}

Two ways Anova Garret [11] is used to investigate the efficacy of neuroscience research-based pedagogy in science achievement among secondary school students (both boys and girls). Statistical tests were chosen as appropriate for the type of data being analyzed. Teaching neuroscience content knowledge was measured with a short pre-and post-test on neuroscience. This test consisted of 75 multiple choice questions with five possible responses and 10 open ended response items. Questions probed understanding of central nervous system processes underlying neuronal function or observable classroom behavior.

\subsection{Results}

The data analysis results pertaining to effect of neuroscience research-based pedagogy on achievement of students in science were presented in Table 3 and 4.

The hypothesis of the present study was students taught through neuroscience research-based pedagogy achieve better in science than the students taught through conventional method. In order to test the hypothesis data was analyzed with the help of two ways Anova and have been depicted in the table below:

Table 3. Difference in the mean of boys and girls in experimental group (E) and of boys control group (C)

\begin{tabular}{|c|c|c|c|c|c|}
\hline Group & Category & Count & Sum & Average & Variance \\
\hline \multirow{2}{*}{$\begin{array}{c}\text { Experimental } \\
\text { group(E) }\end{array}$} & Girls & 18 & 1220 & 66.33 & 10.5 \\
\cline { 2 - 6 } & Boys & 18 & 1194 & 67.78 & 9.10 \\
\hline $\begin{array}{c}\text { Control } \\
\text { group(C) }\end{array}$ & Girls & 18 & 756 & 40.39 & 4.71 \\
\cline { 2 - 6 } & Boys & 18 & 727 & 42.00 & 9.02 \\
\hline
\end{tabular}

The result presented in Table 3 shows that the mean of experimental group for girls is 66.33 and boys is 67.77 and in control group the mean is 40.38 and 42 respectively.

The result shows that significance of the neuroscience research-based pedagogy on the achievement of students in science. The mean score for boys taught through neuroscience research based pedagogy is 67.78 and for girls 66.33. The critical ratio comes out to be $\mathrm{f} 1=5.43$ and $\mathrm{f} 2=10.9$ which is insignificant at 0.01 level of significance. This means the calculated value of ' $\mathrm{f}$ ' is greater than the tabulated value of ' $\mathrm{f}$ '. So the hypothesis is accepted, indicating that the students taught through neuroscience research-based pedagogy will achieve better in science than those taught through conventional method.

\subsection{Discussion}

Brain based learning is a comprehensive approach to instruction using current research from neuroscience Goswami [12]. Brain-based education emphasizes how the brain learns naturally and is based on what we currently know about the actual structure and function of human brain at varying developmental stages. Using the latest neural research, educational techniques that are brain friendly provide a biologically driven framework for creating effective instruction. Learning is brain based but, if we say only learning, people may not understand what we have meant. People have a brain which is wonderful and has infinite opportunities. So, while we are implying the brain-based learning, we are interested in understanding how the brain works best and how we can increase the learning at the highest level.

A study posited that learning is enhanced with brain-based research Bonnema [13]. This study discusses brain-based learning and its relation to classroom instruction. A rapid growing quantity of research currently exists regarding how the brain perceives processes and ultimately learns new information. In order to maximize their teaching efficacy, educators should have a basic understanding of key memory functions in the brain, and how these functions relate to student learning. In this study, the researcher surveys current literature to identify foundational instructional strategies that are supported by brain-based research. Teachers devoted considerable time to neuroscience. The range of activities observed in treatment teachers' classrooms was more laboratory-based and more varied than in comparison classrooms. Multiple activities could be noted for a single class period and data represent the percent of observed classrooms seen incorporating the indicated activity.

Table 4. ANOVA (Two way classification)

\begin{tabular}{|c|c|c|c|c|c|c|}
\hline $\begin{array}{l}\text { Source of } \\
\text { Variation }\end{array}$ & Sum of squares & Degree of Freedom & $\begin{array}{c}\text { Mean } \\
\text { Sum of squares }\end{array}$ & $F$ & $\begin{array}{c}\text { Table value of } \\
F\end{array}$ & Remarks \\
\hline Between the rows & 71172.54 & 17 & 4186.62 & \multirow{3}{*}{$\begin{array}{r}F 1=5.43 \\
F 2=10.90\end{array}$} & \multirow{3}{*}{$\begin{array}{c}0.01 \\
\text { Level }=5.18 \\
0.05 \\
\text { Level }=3.20\end{array}$} & \multirow{3}{*}{$\begin{array}{l}\text { Significance } \\
0.01 \text { level of } \\
\text { significance }\end{array}$} \\
\hline $\begin{array}{l}\text { Between the } \\
\text { columns }\end{array}$ & 25198.46 & 3 & 8399.48 & & & \\
\hline Error & 3927.20 & 51 & 39275.20 & & & \\
\hline
\end{tabular}

Table value at 0.01 level of significance $=3.18$ 


\section{Conclusions}

In the light of the above interpretation of the data, the researcher with care and caution can present the conclusion and generalization of the effectiveness of neuroscience research-based pedagogy in science. Achievement level of children in science taught through neuroscience research based pedagogy is found to be better than achievement level of their counter parts taught through traditional methods. Neuroscience research based pedagogy is found to be effective in influencing the achievement level of children in learning science. Neuroscience is required for all students of education to familiarize them with the orienting concepts of the field, the culture of scientific inquiry, and the special demands of what qualifies as scientifically based education research. Neuroscience is relevant to improving teaching practice and by consequence student learning. Bridging the gap between neuroscience and education requires reforming the role of teachers and the curriculum of teacher education institutions. Neuroscience develops teaching as a profession that is based on scientific literature from multiple disciplines. The neuroscience community, educators, and parents also have to confront false preconceptions about brain-based pedagogy. Research findings in many disciplines, from psychology and genetics to neuroscience and engineering, are already converging to inform curricula and policy.

\section{Recommendations}

- Neuroscience has to make valuable contribution to the development of educational technology.

- Sustainable professional development and training should include elements of neuroscience relevant to educational issues.

- Neuroscience must be used as an instrument in educational policy.

- A knowledge exchange network should be increased required to bridge disciplines.

\section{Acknowledgements}

I would like to thank the administrative bodies of Fassilo general secondary school organization which gave me permission to gather data for the study. It is also my pleasure to thank grade nine students who voluntarily participate in experimental and control group of this study. I also want to express my deepest gratitude to the school principal, vice principal, supervisor and teachers who were actively participated in giving the necessary information to conduct this research.

\section{REFERENCES}

[1] Bruner, J. T. (2005). Education and the Brain: A Bridge too far. Educational Research, 26(8), 4-16. https://doi.org/10.3102/0013189X026008004

[2] McCabe, T. J., \& Castel, N. S. (2016). Emotional intelligence and self-esteem mediate between Perceived early parental love and adult happiness. E-Journal of Applied Psychology: Clinical and Social Issues, 2(2), 38-48.

[3] Weisberg, D., Keil, P., \& Goodstein, E. (2015). Designing and Managing the Supply Chain: Concepts, Strategies and Case Studies (3rd ed.). New York: McGraw-Hill.

[4] Bryan, J. P. and Fox, N. A. (2015). A celebration of neurons: An educator's guide to the human brain, Association for Supervision and Curriculum development, California: Alexandria, VA.

[5] Thompson, P. M., Welcome S. E., Henkenius, A. L. and Toga, A. W. (2011), Mapping critical Change across the human life span, Nature neuroscience, 6(3): 309-315.

[6] Caine, G., \& Caine, R. N. (2010). Making Connection: Teaching and Human Brain. Menlo Park, CA: Addison-Wesley.

[7] Laughbaum, E. D.(2008). Implication of neuroscience Research on teaching algebra: retrieved from continuing Engineering Education and lifelong learning, 18(5/6): 585-597.

[8] Campbell, D. B. (2009). Left Brain-Right Brain (4th ed.). New York: W.H. Freeman and Company.

[9] Garret, E. H. (2012). Statistics in Psychology and Education: Paragon International publisher, Naveen Shahdara, Delhi.

[10] Ministry of education (2011). Concept paper and strategy for improving Science and mathematics education in Ethiopia.

[11] Garret, E. H. (2012). Statistics in Psychology and Education: Paragon International publisher, Naveen Shahdara, Delhi.

[12] Goswami, U. (2013). Neuroscience and education. The British Journal of Educational Psychology, 74 (Pt 1), 1-14. https://doi.org/10.1348/000709904322848798

[13] Bonnema, S. J. (2009). The effect of Brain-based Instruction to Improve Students' Academic Achievement in Social Studies. Journal of Philosophy of Science, 63(4), 515-533. 